\title{
Impact of crop management systems on soil nematode communities in South Brazil
}

\author{
Andressa Cristina Zamboni Machado ${ }^{*}{ }^{*}$, Maurício Rumenos Guidetti Zagatto ${ }^{2}$, Francisco Skora Neto ${ }^{3}$, Santino Aleandro da Silva ${ }^{10}$, \\ Luiz Antonio Zanão Júnior ${ }^{4}$
}

IInstituto de Desenvolvimento Rural do Paraná - Lab. de Nematologia, Rod. Celso Garcia Cid, km 375 - 86047-902 Londrina, PR - Brasil.

2Universidade de São Paulo/ESALQ - Depto. de Ciência do Solo, C.P. 09 - 13418-900 -Piracicaba, SP - Brasil. ${ }^{3}$ Instituto de Desenvolvimento Rural do Paraná -Depto. de Fitotecnia, C.P. 129 - 84001-970 - Ponta Grossa, PR Brasil.

${ }^{4}$ Instituto de Desenvolvimento Rural do Paraná -Depto. de Solos, C.P. 02 - 85825-000 - Santa Tereza do Oeste, PR - Brasil.

*Corresponding author <andressa_machado@idr.pr.gov.br>

Edited by: Paulo Cesar Sentelhas

Received April 06, 2020

Accepted September 28, 2020
ABSTRACT: The analysis of nematode communities allows inferring consequences of management practices on the soil food web. We studied the taxonomic structure of nematode communities in preserved areas of the Atlantic forest (native forest $=$ NF) in Ponta Grossa, Paraná State, Brazil, and in three different agroecosystems in neighboring areas to assess the effect of agricultural land use on nematode assemblages. Agroecosystems were located in a red latosol cropped during 30 years under conventional tillage (CT), no-tillage (NT), and minimal tillage (MT). We collected ten composite soil samples in each area in the summer. Nematodes were extracted by Baermann funnel and fixed with formalin. Subsequently, individuals were classified into taxonomic groups and counted on a Peters slide to determine densities of each taxon. Plant-parasitic and free-living nematodes were classified at the genus level. Data were analyzed with the parameters abundance, Bray \& Curtis, Shannon-Weaver, and Simpson indexes. We recorded 35 genera and abundance of nematodes in MT and NT areas was more similar. Higher richness was observed in NF in relation to cropped areas, especially under NT and CT. The PCA and clustering analyses from both nematode communities and soil chemical characteristics showed that MT and CT were more similar and NT was clustered near NF. The replacement of native vegetation by cropping systems caused a reduction of nematode diversity, demonstrating the influence of agricultural practices on nematode communities.

Keywords: abundance, diversity, taxonomic structure, soil indicators

\section{Introduction}

Nematodes are some of the most diverse soil animals (van den Hoogen et al., 2020) and are capable to respond quickly to environmental changes; therefore, they have been used as indicators of soil health in different crop systems and native areas (Neher, 2001; van den Hoogen et al., 2020). Bacterial-feeding nematodes can ingest a great number of bacterial cells per day and are attracted by high $\mathrm{CO}_{2}$ concentrations in their soil. Their preying capacity releases $\mathrm{NH}_{4}{ }^{+}$readily available to plants and other animals in the soil solution (Lavelle, 1997).

Abundance and diversity of nematodes in fields under different agricultural systems are used to infer disturbances to the soil fauna (van den Hoogen et al., 2019), as well as enrichment and disturbance of soil communities (Bongers, 1990; Ferris et al., 2001; Berkelmans et al., 2003). The intensification of agricultural practices generally leads to biodiversity loss (Matson et al., 1997; Tscharntke et al., 2005), reducing the taxonomic richness of soil nematode communities (Yeates and Bongers, 1999; Yeates and Stirling, 2008).

Reduced tillage practices are used to minimize soil disturbance, as they benefit many soil characteristics, such as soil structure and fauna (Sánches-Moreno et al., 2006). However, most studies focus on the effects of tillage and cropping patterns on plant-parasitic nematodes and, to a lesser extent, on the free-living nematode communities (Sánches-Moreno et al., 2006).

This study investigated the effects of different management systems on nematode communities in preserved areas of the Atlantic Forest in Ponta Grossa,
Paraná State, Brazil, and in neighboring areas, based on plant-parasitic and free-living nematodes. The results are based on studies conducted under field conditions for over 30 years to (a) contribute to the knowledge of nematode diversity (plant-parasitic and free-living) and (b) study the influence of agricultural activities on nematode communities.

\section{Materials and Methods}

\section{Study site}

The samples were collected from a long-term experiment at the municipality of Ponta Grossa, Paraná State, Brazil $\left(25^{\circ} 05^{\prime} 42^{\prime \prime} \mathrm{S}, 50^{\circ} 09^{\prime} 43^{\prime \prime} \mathrm{W}\right.$, altitude of $\left.875 \mathrm{~m}\right)$, which has a Cfb climate, as described by Zagatto et al. (2018). In this study, three types of land use systems were considered, which were kept for 30 years in a Geric Ferralsol (rhodic) according to FAO (FAO, 2006): notillage (NT), conventional tillage $(\mathrm{CT})$, minimum tillage (MT) and a native forest (NF), used as a reference. Soil management was conducted according to Zagatto et al. (2018).

The dimensions of the experimental plots under $\mathrm{CT}$ and MT managements were $100 \times 50 \mathrm{~m}$, and under no-tillage, $100 \times 100 \mathrm{~m}$, with slopes of $6.9,7.1$ and $8.1 \%$, respectively. In these agricultural systems, we collected data on crop succession and weed management since 1995, as described by Zagatto et al. (2018): maize/ black oat/ soybean/ wheat/ soybean/ black oat + vetch. The $\mathrm{NF}$ was a remnant of mixed Ombrophilous forest and comprised an adjacent area with $100 \times 100 \mathrm{~m}$. 


\section{Soil sampling and nematode identification}

Soil samples were collected in the summer $(25 \mathrm{Feb}$ 2011). Ten samples from each treatment $(\mathrm{n}=10)$ were collected at $0-10 \mathrm{~cm}$ deep, totaling $1 \mathrm{~kg}$ of soil. Nematodes were extracted from a subsample of $50 \mathrm{~cm}^{3}$ using the Baermann funnel method, as described in Machado et al. (2010), and later fixed in TAF (formalin $40 \%$, triethanolamine, distilled water). All nematodes in each sample were counted at low magnification $(40 \times)$ and then identified at the genus level at higher magnification $(100 \times)$, according to De Ley and Blaxter (2002).

At each sampling point, soil samples were also analyzed for chemical attributes and characterization is shown in Table 1.

\section{Statistical analysis}

Relative abundance of each taxon was calculated from the proportion of that taxon among the nematodes identified. Abundance was expressed as the number of nematodes in each taxon. Posteriorly, usual indicators for ecological studies were calculated: Richness (number of genera), the Simpson diversity index, the ShannonWeaver diversity index, and the Bray and Curtis similarity index, using the vegan package /Oksanen et al., 2019) in R 2.15 program.

The dataset was submitted to principal component analysis (PCA) and later to the hierarchical clustering analysis. Based on the cophenetic matrix, the grouping method was the UPGMA. This multivariate analysis allowed determining the most robust discriminant variable and obtaining an overview of similarities between the management systems, based on nematode communities and the soil chemical analysis. We used the canonical correspondence analysis (CCA), a multivariate constrained ordination technique, to observe the combinations between chemical characteristics and nematode-feeding groups. All multivariate analyses were performed with the vegan package (Oksanen et al., 2019) in R 2.15 program.

\section{Results}

\section{Influence of management practices on soil nematode community}

Thirty-five nematode genera were identified in the samples collected (Table 2), which were affiliated to six orders of Adenophorea (Araeolaimida, Diplogasterida, Dorylaimida, Enoplida, Mononchida, and Triplonchida) and two orders of Secernentea (Rhabditida and Tylenchida). We verified 20 genera in CT, 32 in MT, 14 in NT and 32 in NF (Table 3).

We identified 15,571 nematodes/kg of soil in $\mathrm{CT}$, with more than $70 \%$ belonging to five genera/family: Aphelenchus (17.9\%), Cephalobus (5.4\%), Helicotylenchus (16.5\%), Prismatolaimus (5.2\%) and Rhabditidae (25.9\%). In $\mathrm{MT}$, we verified 27,212 nematodes/kg with more than $77 \%$ belonging to six genera/family: Aphelenchus (23.4 \%), Dorylaimoides (4.4\%), Helicotylenchus (18.1\%), Labronema (5.1\%), Tylenchus (4.3\%) and Rhabditidae $(22.5 \%)$. On the other hand, in NT, we identified 6,891 nematodes/kg of soil, with more than $63 \%$ belonging to two genera: Aphelenchus (19.6\%) and Helicotylenchus (44.1\%), while NF showed 12,338 nematodes/kg of soil, with more than $60 \%$ belonging to three genera: Meloidogyne (21.8 \%), Mesocriconema (24.8 \%) and Xiphinema (13.7\%).

The Shannon-Weaver $\left(\mathrm{H}^{\prime}\right)$ diversity index confirmed the indications based on number of genera (or richness) relatively to the high diversity found in NF and MT samples (Table 3). The Bray and Curtis index (Table 4), based on quantitative values of abundance, evidenced that MT and CT areas were more similar, while MT was more dissimilar to NF.

\section{Soil chemical attributes effects on nematode community}

The PCA and clustering analyses showed variability between the management systems for nematode communities and soil chemical attributes (Figures $1 \mathrm{~A}$ and $1 \mathrm{~B})$. Based on nematode community composition

Table 1 - Chemical analysis of soil from different management systems (NT = no tillage, $\mathrm{CT}=$ conventional tillage, MT = minimal tillage, NF $=$ native forest) collected at 0-5 and 5-10 cm, in the municipality of Ponta Grossa, Paraná State, Brazil.

\begin{tabular}{|c|c|c|c|c|c|c|c|c|c|c|}
\hline & $\begin{array}{c}\mathrm{pH} \\
\mathrm{CaCl}_{2}\end{array}$ & $P$ & K & $\mathrm{Al}^{3+}$ & $\mathrm{Ca}^{2+}$ & $\mathrm{Mg}^{2+}$ & $\mathrm{H}+\mathrm{Al}$ & $\mathrm{T}$ & V & C \\
\hline & & $\mathrm{dm}^{-3}$ & & & $-\mathrm{cn}$ & $1^{3}$ & & - & $\%$ & $\mathrm{~g} \mathrm{dm}^{-3}$ \\
\hline NT $0-5 \mathrm{~cm}$ & 4.33 & 21.58 & 0.24 & 0.53 & 3.32 & 1.35 & 10.18 & 15.09 & 32.4 & 39.8 \\
\hline NT $5-10 \mathrm{~cm}$ & 4.31 & 11.55 & 0.16 & 0.84 & 2.20 & 0.94 & 8.56 & 11.86 & 27.2 & 28.4 \\
\hline MT 0-5 cm & 4.40 & 8.68 & 0.20 & 0.42 & 2.96 & 1.23 & 8.24 & 12.63 & 34.5 & 31.6 \\
\hline MT $5-10 \mathrm{~cm}$ & 4.49 & 7.62 & 0.11 & 0.38 & 2.87 & 1.17 & 7.54 & 11.68 & 35.3 & 26.9 \\
\hline СТ $0-5 \mathrm{~cm}$ & 4.34 & 7.31 & 0.22 & 0.48 & 2.57 & 1.08 & 15.62 & 19.49 & 32.1 & 27.6 \\
\hline CT $5-10 \mathrm{~cm}$ & 4.37 & 7.09 & 0.12 & 0.50 & 2.56 & 1.04 & 7.62 & 11.34 & 32.8 & 26.7 \\
\hline NF $0-5 \mathrm{~cm}$ & 4.24 & 4.16 & 0.32 & 1.13 & 3.68 & 1.68 & 11.97 & 17.65 & 32.1 & 46.2 \\
\hline $\mathrm{NF} 5-10 \mathrm{~cm}$ & 4.11 & 1.89 & 0.21 & 1.57 & 1.60 & 0.82 & 11.49 & 14.11 & 17.7 & 32.7 \\
\hline
\end{tabular}

$\mathrm{P}, \mathrm{K}$ (Mehlich-1); Al, $\mathrm{Ca}, \mathrm{Mg}=(\mathrm{KCl}) ; \mathrm{T}=$ cation exchange capacity at $\mathrm{pH} 7.0 ; \mathrm{V} \%$ = saturation of the cationic complex by bases. 
Table 2 - Effect of tillage system on total abundance of nematode taxa (number of nematodes / $50 \mathrm{~cm}^{3}$ soil). Data from four sampling experimental plots $(n=40)$.

\begin{tabular}{|c|c|c|c|c|c|c|}
\hline Order & Trophic group ${ }^{a}$ & Genera & Conventional tillage & Minimal tillage & No tillage & Native Forest \\
\hline \multirow[t]{2}{*}{ Aphelenchida } & $\mathrm{PP} / \mathrm{FF}$ & Aphelenchoides & - & $8.10 \pm 25.61$ & - & $16.55 \pm 41.44$ \\
\hline & $\mathrm{PP} / \mathrm{FF}$ & Aphelenchus & $139.25 \pm 75.32$ & $318.45 \pm 200.37$ & $67.60 \pm 35.49$ & $15.15 \pm 21.00$ \\
\hline Araeolaimida & $\mathrm{BF}$ & Plectus & $1.25 \pm 3.95$ & $3.60 \pm 7.59$ & - & $0.65 \pm 2.05$ \\
\hline Diplogasterida & & Mononchoides & $18.40 \pm 15.07$ & $16.05 \pm 29.63$ & - & $0.90 \pm 2.84$ \\
\hline \multirow[t]{13}{*}{ Dorylaimida } & PR & Carcharolaimus & - & $0.90 \pm 2.84$ & - & - \\
\hline & PR & Discolaimus & - & $9.75 \pm 18.80$ & - & $8.80 \pm 23.61$ \\
\hline & PR & Discolaimoides & $4.35 \pm 13.75$ & - & - & $6.95 \pm 16.24$ \\
\hline & $\mathrm{OM}$ & Dorylaimoides & $24.75 \pm 19.69$ & $59.85 \pm 65.59$ & $25.90 \pm 36.02$ & $15.35 \pm 23.60$ \\
\hline & OM & Dorylaimus & - & $39.75 \pm 54.72$ & - & $4.80 \pm 10.97$ \\
\hline & $\mathrm{OM}$ & Labronema & $3.85 \pm 9.10$ & $69.85 \pm 80.12$ & - & $0.55 \pm 1.74$ \\
\hline & $\mathrm{OM}$ & Laimydorus & $32.65 \pm 39.95$ & $19.00 \pm 56.65$ & - & $0.90 \pm 2.84$ \\
\hline & $\mathrm{OM}$ & Mesodorylaimus & $4.30 \pm 9.57$ & $9.20 \pm 12.79$ & $15.75 \pm 12.63$ & $4.25 \pm 5.97$ \\
\hline & $\mathrm{OM}$ & Prodorylaimus & $18.30 \pm 15.57$ & $1.25 \pm 3.95$ & - & - \\
\hline & PP & Trichodorus & $14.80 \pm 20.28$ & $15.30 \pm 25.73$ & $3.70 \pm 7.92$ & $3.90 \pm 7.28$ \\
\hline & $\mathrm{FF}$ & Tylencholaimus & - & - & - & $0.55 \pm 1.74$ \\
\hline & PP & Xiphidorus & - & $7.50 \pm 20.75$ & - & $9.60 \pm 14.47$ \\
\hline & PP & Xiphinema & - & $2.80 \pm 4.51$ & - & $85.15 \pm 61.74$ \\
\hline Enoplida & $\mathrm{BF}$ & Prismatolaimus & $40.40 \pm 43.37$ & $22.90 \pm 31.42$ & $13.80 \pm 23.54$ & $21.05 \pm 33.57$ \\
\hline \multirow[t]{3}{*}{ Mononchida } & PR & Mononchus & $15.00 \pm 16.67$ & $7.90 \pm 8.56$ & $2.40 \pm 5.25$ & $5.65 \pm 12.85$ \\
\hline & PR & Mylonchulus & $1.40 \pm 4.42$ & $21.70 \pm 28.14$ & - & $3.00 \pm 9.48$ \\
\hline & PR & Prionchulus & - & $1.65 \pm 5.22$ & - & $2.75 \pm 8.69$ \\
\hline \multirow[t]{6}{*}{ Rhabditida } & $\mathrm{BF}$ & Acrobeles & $3.25 \pm 5.36$ & $7.80 \pm 7.99$ & $8.22 \pm 8.21$ & $2.35 \pm 5.76$ \\
\hline & $\mathrm{BF}$ & Acrobeloides & - & $5.40 \pm 17.07$ & - & $8.25 \pm 17.13$ \\
\hline & $\mathrm{BF}$ & Cephalobus & $42.35 \pm 38.61$ & $16.60 \pm 27.04$ & $8.00 \pm 13.75$ & $0.65 \pm 2.05$ \\
\hline & $\mathrm{BF}$ & Eucephalobus & - & $2.55 \pm 5.66$ & - & $0.55 \pm 1.74$ \\
\hline & $\mathrm{BF}$ & Panagrolaimus & - & $13.05 \pm 41.27$ & - & $7.85 \pm 16.55$ \\
\hline & $\mathrm{BF}$ & Rhabditidae & $202.00 \pm 122.43$ & $305.90 \pm 179.78$ & $17.15 \pm 22.22$ & $24.80 \pm 29.45$ \\
\hline Triplonchida & PP & Paratrichodorus & - & $15.00 \pm 21.21$ & - & $1.50 \pm 4.74$ \\
\hline \multirow[t]{7}{*}{ Tylenchida } & & Filenchus & $1.90 \pm 4.03$ & $16.95 \pm 20.05$ & $4.45 \pm 8.64$ & $8.55 \pm 15.83$ \\
\hline & PP & Helicotylenchus & $128.60 \pm 65.17$ & $246.45 \pm 250.07$ & $151.95 \pm 76.53$ & $19.30 \pm 27.34$ \\
\hline & PP & Meloidogyne & $78.40 \pm 64.22$ & - & - & $135.05 \pm 208.52$ \\
\hline & PP & Mesocriconema & - & $10.35 \pm 26.19$ & - & $154.10 \pm 415.89$ \\
\hline & PP & Paratylenchus & - & $3.70 \pm 8.77$ & - & $10.60 \pm 17.59$ \\
\hline & PP & Pratylenchus & $3.35 \pm 5.68$ & $20.85 \pm 62.83$ & $0.95 \pm 2.00$ & - \\
\hline & PP & Tylenchus & - & $58.85 \pm 41.72$ & $18.25 \pm 16.47$ & $36.90 \pm 65.89$ \\
\hline
\end{tabular}

aPP = plant-parasitic; PR = predator; $\mathrm{BF}=$ bacterial-feeder; $\mathrm{OM}=$ omnivores; $\mathrm{FF}$ = fungal-feeders; $\mathrm{PP} / \mathrm{FF}=$ variable between plant-parasitic and fungal-feeder.

Table 3 - Nematode diversity in the soil sampled in different cropping systems and native forest in South Brazil.

\begin{tabular}{lcccc}
\hline Index & Conventional tillage & Minimal tillage & No tillage & Native Forest \\
\hline Richness & 20 & 32 & 14 & 32 \\
H' $^{\prime}$ & 0.97 & 1.04 & 0.80 & 1.06 \\
$\mathrm{~J}^{\prime}$ & 0.74 & 0.69 & 0.70 & 0.70 \\
\hline
\end{tabular}

Richness = number of genera; $H^{\prime}=$ Shannon-Weaver diversity index; $J^{\prime}=$ Simpson index.

(Figure 1A), CT was grouped by the clustering analysis with MT, whereas NT formed a separate group near $\mathrm{NF}$, in accordance with to the Bray and Curtis index classification. The soil chemical analysis (Figure 1B) showed that NF was grouped with NT, while MT was grouped with CT.
Table 4 - Relationships between native forest (NF), minimal tillage (MT), conventional tillage (CT) and no-tillage (NT) areas, based on nematode community similarities accessed by Bray and Curtis index calculated from total abundance.

\begin{tabular}{cc}
\hline & Bray and Curtis \\
\hline $\mathrm{NF} \times \mathrm{MT}$ & 0.77 \\
$\mathrm{NF} \times \mathrm{NT}$ & 0.75 \\
$\mathrm{NF} \times \mathrm{CT}$ & 0.71 \\
$\mathrm{MT} \times \mathrm{NT}$ & 0.61 \\
$\mathrm{MT} \times \mathrm{CT}$ & 0.43 \\
$\mathrm{NT} \times \mathrm{CT}$ & 0.50 \\
\hline
\end{tabular}

The canonical correspondence analysis (Figure 2) performed with data of nematode community and the soil chemical analysis showed that NF was positively correlated to higher concentrations of $\mathrm{Al}$ and $\mathrm{C}$, whereas 
MT and NT were correlated to P concentrations. Other soil characteristics were not significant in the analysis and were excluded from the graphic representation. Regarding nematode communities (Figure 2), MT and

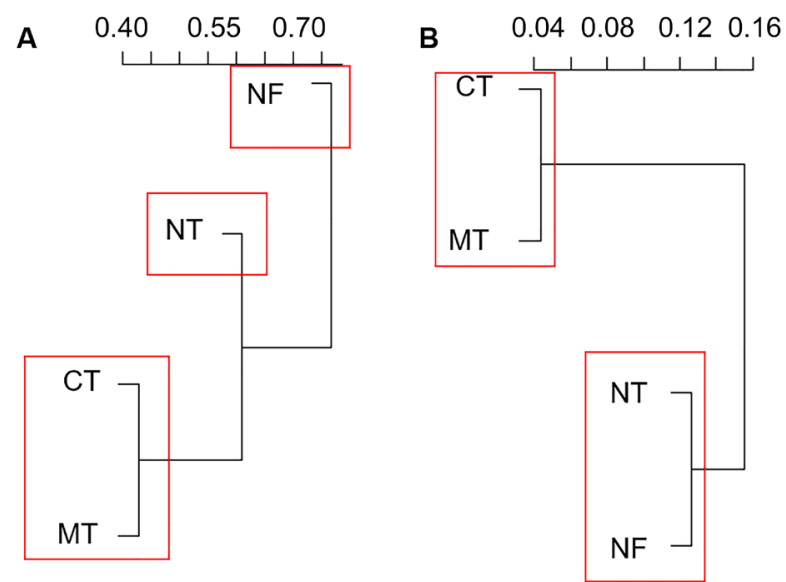

Figure 1 - Dendrogram illustrating the dissimilarity between treatments $(\mathrm{NF}=$ native forest; $\mathrm{NT}=$ no-tillage; $\mathrm{MT}=$ minimal tillage; $\mathrm{CT}$ = conventional tillage) obtained by the UPGMA algorithm, based on the Euclidean distance, calculated from the average of nematode-feeding groups (A) and the soil chemical analysis (B).
NT were correlated to $\mathrm{P}$ content and omnivores, plantparasitic, and to predators, to a lesser extent. NF was correlated to fungal-feeders, plant-parasitic nematodes, and high $\mathrm{Al}$ content, while CT was not correlated to the chemical analysis; nevertheless, it was correlated to bacterial-feeders and predators.

\section{Discussion}

Studies conducted in Uruguay and Brazil showed that discrimination of different cropping systems using only abundance values was not applicable, when native areas were compared to cropped areas (Korenko and Schmidt, 2007; Tomazini et al., 2008). However, in systems under more intensive cropping, such as CT and MT, values of total density were higher. Several authors reported the predominance of higher density values in areas submitted to more intensive cultural traits when compared to native areas (Andrade et al., 2004; Goulart and Ferraz, 2003; Mattos et al., 2006), in Brazilian ecosystems. This can be explained as some crops host plant-parasitic species in the field, increasing the number of nematodes in the samples, as observed for Helicotylenchus and Aphelenchus in our study. Yeates and King (1997) and Valocká et al. (2001) compared nematode communities in native pastures with

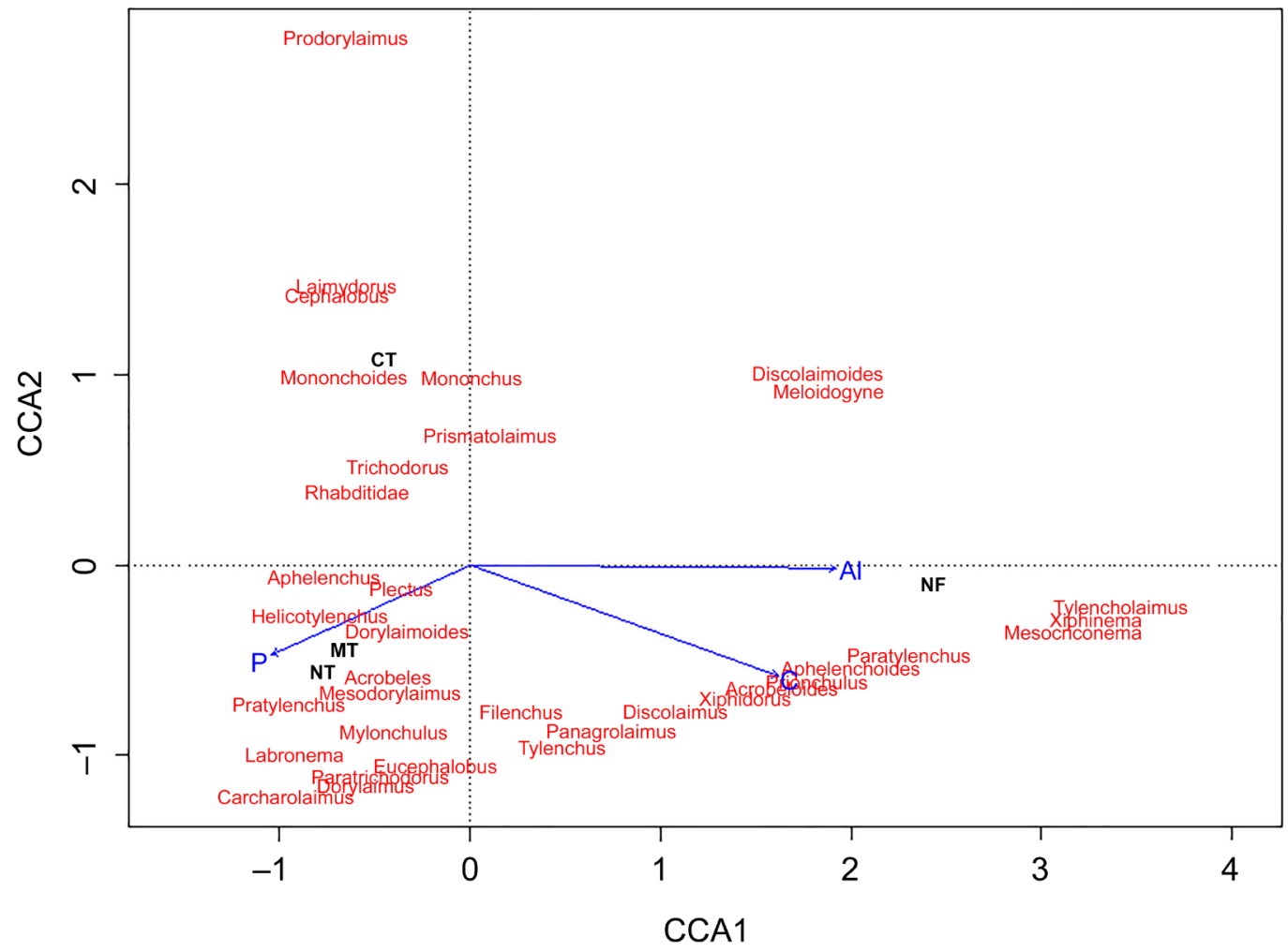

Figure 2 - Canonical correspondence analysis bi-plot of association of soil properties ( $P=$ phosphorus; $C=$ carbon; $A l=$ aluminum) and nematode community in different crop systems (NF = native forest; $\mathrm{MT}=$ minimal tillage; $\mathrm{CT}=$ conventional tillage; NT = no-tillage). Data represent all samples combined $(n=40)$. Eigenvalues (lambda) are $0.5113,0.1273$, and 0.1001 for the first (horizontal), second (vertical) and third axes, respectively. The first two axes explained $64.8 \%$ of the variation. 
cropped areas and observed that disturbances caused by agricultural practices increased the total abundance and richness of nematodes. This is possibly due to the increase in plant-parasitic nematode population, which could be so small in the soil and not be detected without the presence of the host plant.

Dorylaimida, such as Labronema and Discolaimoides, is cited as abundant in Cerrado soils and little detected in cropped soils (Goulart and Ferraz, 2003); however, in this study, both species occurred in cropped areas, demonstrating low sensibility to agricultural land use. In addition, agricultural crops could increase abundance of bacterial-feeding nematodes, especially due to the presence of organic matter (Shaw et al., 2019) and fungalfeeders, which sporadically parasitize on aerial parts of plants and could be favored or introduced by seeds of the agricultural crops (Yeates, 1991).

Mesocriconema, of the order Tylenchida, was observed in higher abundance in $\mathrm{NF}$, demonstrating that this nematode is more sensitive to disturbances caused by the agricultural practices, such as tillage (Cares and Huang, 1991; Yeates, 1991; Gomes et al., 2003). In the Cerrado region of Brazil, nematodes of Criconematidae family have played an important role in distinguishing native from cropped areas (Mattos et al., 2008), since they are very sensitive to disturbances resulting from the replacement of native areas by annual crops (Goulart and Ferraz, 2003). Other genera from Tylenchida were present in all sampled areas, but with great variation in the density values, such as Helicotylenchus, the dominant genus in Tylenchida in this study, possibly favored by soybean cropping in CT and MT (Machado et al., 2019). The same can be concluded for Mononchida, found in all sampled areas and in great variation. These nematodes are predators and supposedly sensitive to environmental changes (Niles and Freckman, 1998; Wasilewska, 1997); nevertheless, they were not observed in our study.

The Shannon-Weaver and the Bray and Curtis indexes showed high diversity in NF and MT samples and that these areas were more similar. Conversely, CT was more dissimilar to NT. These observations corroborated previous reports in which the number and richness of genera or species sometimes constitutes better tools to evaluate nematode diversity in different ecosystems (Mattos et al., 2006); nevertheless, the efficiency of these parameters is controversy in literature. Freckman and Ettema (1993) considered richness and the ShannonWeaver index little useful in distinguishing annual from perennial crops, while Yeates and Bird (1994) and McSorley and Frederick (1996) considered these approaches efficient.

In addition, cropped areas, except for MT, have a lower richness than NF. These findings agree with most similar studies in the literature, which report a higher number of taxa in native vegetation than in cropped areas (Freckman and Ettema, 1993; Háněl, 1995; Yeates and King, 1997; Mattos et al., 2006; Goulart and Ferraz, 2003; Gomes et al., 2003; Tomazini et al., 2008).
Regarding the effect of soil chemical attributes on nematode communities, NF was positively correlated to higher $\mathrm{Al}$ and $\mathrm{C}$ concentrations, whereas $\mathrm{MT}$ was correlated to $\mathrm{P}$ concentration. Thus, we can infer that high $\mathrm{Al}$ concentration is characteristic of this native type of soil where the experiment was conducted, that is, Campos Gerais, characterized by poor and washed soils, deficient in $\mathrm{P}, \mathrm{Ca}, \mathrm{N}$, and $\mathrm{K}$, with low $\mathrm{pH}$ and Al high concentration (Bodziak Júnior and Maack, 2001). The low pH observed in these soils could lead to an increase in the $\mathrm{Al}$ toxicity, which might reduce microbial biomass, generally observed after $\mathrm{N}$ addition to the soil (Shaw et al., 2019), influencing soil nematode communities, especially those dependent on microbial biomass.

The analysis of feeding groups provides information on changes in decomposition pathways between the sites studied. Abundance of bacterialfeeders could increase due to the microbial activity caused by fertilization or accelerated decomposition (Ettema and Bongers, 1993) and respond to OM input depending on the quantity and quality of OM (DuPont et al., 2009). Nevertheless, several bacteria in agricultural fields can solubilize insoluble forms of $\mathrm{P}$ to make them available for plant growth and have been considered as predominant source of $\mathrm{P}$ availability (Ilmer and Schinner, 1992). In our samples, bacterial-feeders were also correlated with the $\mathrm{P}$ content, possibly due to high concentration of P-solubilizing bacteria.

On the other hand, enrichment opportunist fungal-feeding nematodes react rapidly to the addition of organic materials, because fungal-feeders have high respiration rates and low $\mathrm{N}$ needs, mineralizing $\mathrm{N}$ to plants (Chen and Ferris, 1999; Ferris et al., 1997). This information if confirmed by our study where fungal-feeders were correlated with high $\mathrm{C}$ concentration. Besides, the higher concentration of $\mathrm{C}$ was also correlated with NF samples, reflecting the decomposition pathway of natural forests, predominantly by fungal-feeding nematodes. Besides, the black oat and wheat crops could explain high abundance of Aphelenchus in CT and MT in the winter, since these plant species can host this genus and favor the increase of its populations in the soil (Singh et al., 2013).

Therefore, these results may serve as link between microorganism and energy flow in the soils analyzed, providing a valuable tool to access the nature of decomposition pathways. Population of fungal- and bacterial-feeders are useful for tracking disturbances within a crop system, although the responses of nematode communities to agricultural intensification are not easy to interpret and correlate to soil properties (Sánchez-Moreno et al., 2006). Nematode communities can differentiate diverse habitats or cropping systems, especially in large temporal or land scales experiments (Levin, 1992). Therefore, we observed that nematode communities were capable of grouping MT and CT 
in a separate cluster from NT and NF, indicating that aggressive cropping systems differ from conservative ones. Popovici and Ciobanu (2000) also found correlation between the composition of the nematode community and habitat characteristics, as different vegetation and crop systems.

In summary, the analyses of nematode communities successfully reported shifts in land use after 30 years in a field experiment in southern Brazil. Abundance of nematodes demonstrated that MT and NT areas were more similar and CT was more dissimilar to NT. Besides, cropped areas, except under MT, have a lower richness than NF. The PCA and clustering analysis also discriminated the impact of land use in the soil nematode communities, since NF was grouped with NT and MT with CT, based on the soil chemical analysis and nematode communities. These results indicated that nematode diversity is important for long-term stability of soil ecosystem and its use as soil health indicators merits further studies covering larger areas under soil conservation systems, such as NT and intercropping in Brazil.

\section{Acknowledgments}

The first author would like to thank the Brazilian National Council for Scientific and Technological Development (CNPq) for the grants awarded.

\section{Authors' Contributions}

Conceptualization: Machado, A.C.Z.; Zagatto, M.R.G.; Skora Neto, F.; Silva, S.A.; Zanão Júnior, L.A. Data acquisition: Zagatto, M.R.G.; Skora Neto, F.; Zanão Júnior, L.A. Data analysis: Silva, S.A. Design of methodology: Machado, A.C.Z.; Zagatto, M.R.G.; Skora Neto, F.; Zanão Júnior, L.A. Writing and editing: Machado, A.C.Z.; Zagatto, M.R.G.; Silva, S.A.; Zanão Júnior, L.A.

\section{References}

Andrade, E.P.; Huang, S.P.; Miranda, C.H.B. 2004. Nematode communities in eight land use systems in Mato Grosso do Sul. Fitopatologia Brasileira 29: 186 (in Portuguese, with absctract in English).

Berkelmans, R.; Ferris, H.; Tenuta, M.; van Bruggen, A.H.C. 2003. Effects of long-term crop management on nematode trophic levels other than plant-feeders disappear after 1 year of disruptive soil management. Applied Soil Ecology 23: 223-235. DOI: https://doi.org/10.1016/S0929-1393(03)00047-7

Bodziak Júnior, C.; Maack, R. 2001. Contribution to the knowledge of the soils from Campos Gerais in the State of Paraná. Brazilian Archives of Biology and Technology 1: 197214 (in Portuguese, with abstract in English).

Bongers, T. 1990. The maturity index: an ecological measure of environmental disturbance based on nematode species composition. Oecologia 83: 14-19.
Cares, J.P.; Huang, S.P. 1991. Nematode fauna in natural and cultivated cerrados of central Brazil. Fitopatologia Brasileira 16: 199-209.

Chen, J.; Ferris, H. 1999. The effects of nematode grazing on nitrogen mineralization during fungal decomposition of organic matter. Soil Biology and Biochemistry 31: 1265-1279. DOI: https://doi.org/10.1016/S0038-0717/99)00042-5

De Ley, P.; Blaxter, M.M. 2002. Systematic position and phylogeny. p. 1-30. In: Lee, D.L., ed. The biology of nematodes. CRC Press, Boca Raton, FL, USA.

DuPont, S.T.; Ferris, H.; Hom, M.V. 2009. Effects of cover crop quality and quantity on nematode-based soil food webs and nutrient cycling. Applied Soil Ecology 41: 157-167. DOI: https://doi.org/10.1016/j.apsoil.2008.10.004

Ettema, C.H.; Bongers, T. 1993. Characterization of nematode colonization and succession in disturbed soil using the maturity index. Biology and Fertility of Soils 16: 79-85.

Food and Agriculture Organization [FAO]. 2006. World Reference Base for Soil Resources: A Framework for International Classification, Correlation and Communication. IUSS/ISRIC/FAO, Rome, Italy.

Ferris, H.; Vanette, R.C.; Lau, S.S. 1997. Population energetics of bacterial-feeding nematodes: carbon and nitrogen budgets. Soil Biology and Biochemistry 29: 1183-1194. DOI: https://doi. org/10.1016/S0038-0717(97)00035-7

Ferris, H.; Bongers, T.; de Goede, R.G.M. 2001. A framework for soil food web diagnostics: extension of the nematode faunal analysis concept. Applied Soil Ecology 18: 13-29. DOI: https:// doi.org/10.1016/S0929-1393(01)00152-4

Freckman, D.W.; Ettema, C.H. 1993. Assessing nematode communities in agroecosystems of varying human intervention. Agriculture, Ecosystems and Environment 45: 239-261. DOI: https://doi.org/10.1016/0167-8809/93/90074-Y

Gomes, G.S.; Huang, S.P.; Cares, J.E. 2003. Nematode community, trophic structure and population fluctuation in soybean fields. Nematologia Brasileira 28: 258-266.

Goulart, A.M.C.; Ferraz, L.C.C.B. 2003. Study of nematode communities in native and cultivated vegetation. 1 . Trophic diversity. Nematologia Brasileira 27: 123-128 (in Portuguese, with abstract in English).

Háněl, L. 1995. Secondary successional stages of soil nematodes in cambisols of south Bohemia. Nematologica 41: 197-218.

Ilmer, P.; Schinner, F. 1992. Solubilization of inorganic phosphate by microorganisms isolated from forest soils. Soil Biology and Biochemistry 24: 389-395. DOI: https://doi.org/10.1016/00380717(92)90199-8

Korenko, V.; Schmidt, C. 2007. Effects of agricultural practices in the rice crop system on nematode communities in Uruguay. Nematologia Mediterranea 34: 151-159.

Lavelle, P. 1997. Faunal activities and soil processes: adaptive strategies that determine ecossystem function. Advances in Ecology Research 27: 93-132.

Levin, S.A. 1992. The problem of pattern and scale in ecology. Ecology 73: 1943-1967.

Machado, A.C.Z.; Siqueira, K.M.S.; Araújo Filho, J.V. Methods and Techniques in Plant Nematology. VDM-Verlag: Germany, pp. 21-37.

Machado, A.C.Z.; Amaro, P.M.; Silva, S.A. 2019. Two novel potential pathogens for soybean. PLoS ONE 14: e0221416. DOI: https://doi.org/10.1371/journal.pone.0221416 
Matson, P.A.; Parton, W.J.; Power, A.G.; Swift, M.J. 1997. Agricultural intensification and ecosystem properties. Science 277: 504-509. DOI: http://dx.doi.org/10.1126/ science.277.5325.504

Mattos, J.K.A.; Huang, S.P.; Pimentel, C.M.M. 2006. Trophic groups of nematode communities in soils present in soils from the Cerrado region of Central Brazil. Nematologia Brasileira 30: 267-273 (in Portuguese, with abstract in English).

Mattos, J.K.A.; Andrade, E.P.; Teixeira, M.A.; Castro, A.P.G.; Huang, S.P. 2008. Key-genera of eleven different nematode communities present in soils from the Cerrado region of Central Brazil. Nematologia Brasileira 32: 142-149 (in Portuguese, with abstract in English).

McSorley, R.; Frederick, J.J. 1996. Nematode community structure in rows and between rows of a soybean field. Fundamental and Applied Nematology 19: 251-261.

Neher, D.A. 2001. Role of nematodes in soil health and their use as indicators. Journal of Nematology 33: 161-168.

Niles, R.K.; Freckman, D.W. 1998. From the ground up: nematode ecology in bioassessment and ecosystem health. p. 65-85. In: Bartels, J.M., ed. Plant and nematode interactions. ASA/ CSSA/ SSSA, Madison, WI, USA.

Oksanen, J.; Blanchet, F.G.; Friendly, M.; Kindt, R.; Legendre, P.; McGlinn, D.; Minchin, P.R.; O'Hara, R.B.; Simpson, G.L.; Solynos, P.; Henry, M.; Stevens, H.; Szoecs, E.; Wagner, H. 2019. Package 'vegan'. Available at: https://github.com/vegandevs/ vegan [Accessed Aug 8, 2018]

Popovici, I.; Ciobanu, M. 2000. Diversity and distribution of nematode community in grassland from Romania in relation to vegetation and soil characteristics. Applied Soil Ecology 14: 27-36. DOI: https://doi.org/10.1016/S0929-1393(99)00048-7

Sánchez-Moreno, S.; Minoshima, H.; Ferris, H.; Jackson, L.E. 2006. Linking soil properties and nematode community composition: effects of soil management on soil food webs. Nematology 8: 703-715. DOI: https://doi.org/10.1163/156854106778877857

Shaw, E.A.; Boot, C.M.; Moore, J.C.; Wall, D.H.; Baron, J.S. 2019. Long-term nitrogen addition shifts the soil nematode community to bacterivore-dominated and reduces its ecological maturity in a subalpine forest. Soil Biology and Biochemistry 130: 177-184. DOI: https://doi.org/10.1016/j. soilbio.2018.12.007

Singh, S.K.; Hodda, M.; Ash, G.J. 2013. Plant-parasitic nematodes of potential phytosanitary importance, their main hosts and reported yield losses. Bulletin OEPP 43: 334-374. DOI: https:// doi.org/10.1111/epp.12050
Tomazini, M.D.; Ferraz, L.C.C.B.; Monteiro, A.R. 2008. Abundance and diversity of nematodes in contiguous areas of natural vegetation and submitted to different types of agricultural uses. Nematologia Brasileira 32: 185-193 (in Portuguese, with abstract in English).

Tscharntke, T.; Klein, A.M.; Kruess, A.; Steffan-Dewenter, I.; Thies, C. 2005. Landscape perspectives on agricultural intensification and biodiversity: ecosystem service management. Ecology Letters 8: 857-874. DOI: https://doi.org/10.1111/j.14610248.2005.00782.x

Valocká, B.; Sabová, M.; Renco, M. 2001. Soil and plant nematode communities of two types of ecosystems. Helminthologia 38: 105-109.

van den Hoogen, J.; Geisen, S.; Routh, D. 2019. Soil nematode abundance and functional group composition at a global scale. Nature Research 572: 194-198. DOI: https://doi.org/10.1038/ s41586-019-1418-6

van den Hoogen, J.; Geisen, S.; Wall, D.H. 2020. A global database of soil nematode abundance and functional group composition. Nature Scientific Data 7: 103. DOI: https://doi.org/10.1038/ s41597-020-0437-3

Wasilewska, L. 1997. Soil invertebrates as biondicators, with special reference to soil-inhabiting nematodes. Russian Journal of Nematology 5: 113-126.

Yeates, G.W. 1991. Impact of historical changes in land use on the soil fauna. New Zealand Journal of Ecology 15: 99-106.

Yeates, G.W. 2003. Nematodes as soil indicators: functional and biodiversity aspects. Biology and Fertility of Soils 37: 199-210.

Yeates, G.W.; Bird, A.F. 1994. Some observations on the influence of agricultural practices on the nematode faunae of some South Australian soils. Fundamental and Applied Nematology 17: 133-145.

Yeates, G.W.; Bongers, T. 1999. Nematode diversity in agroecosystems. Agriculture, Ecosystems and Environment 74: 113-135.

Yeates, G.W.; King, K.L. 1997. Soil nematodes as indicators of the effect of management of grasslands in the New England Tablelands (NSW): comparison of native and improved grasslands. Pedobiologia 41: 526-536.

Yeates, G.W.; Stirling, G.R. 2008. Regional patterns among soil nematode assemblages in Australasian pastures and effects of management practices. Australasian Plant Pathology 37: 298307. 